Annals of Warsaw University of Life Sciences - SGGW

Land Reclamation No 49 (2), 2017: 57-68

(Ann. Warsaw Univ. of Life Sci. - SGGW, Land Reclam. 49 (2), 2017)

\title{
Determining the spacing of ridge terraces on arable land in central and south-western Poland
}

\author{
ANNA BARYŁA ${ }^{1}$, ROMUALD ŻMUDA ${ }^{2}$ \\ ${ }^{1}$ Faculty of Civil and Environmental Engineering, Warsaw University of Life Sciences - SGGW \\ ${ }^{2}$ Institute of Environmental Protection and Development, Wroclaw University of Environmental \\ and Life Sciences
}

\begin{abstract}
Determining the spacing of ridge terraces on arable land in central and south-western Poland. The practice of many countries has shown that terraces can significantly prevent land degradation processes such as excessive soil erosion, landslides. Condition is good layout, proper construction, and then proper maintenance. Practical application in many countries showed that terraces can significantly prevent processes leading to the degradation of land, such as the excessive erosion of soils and landslides. The requirement for this is well-planned, adequate construction, and later proper conservation. In Poland this is a little popular method. In the article, the dorsal spacing terraces were calculated for two catchments - in the central and south-western parts of Poland. Meteorological and soil data were used for Puczniew station (Ner catchment) and Boleścin station (Mielnica catchment). Kolmogorov-Smirnov test was performed to assess the compatibility of a given feature with a normal distribution, then the distribution of the probability distribution was developed. For probability 1,50 and $90 \%$ the spacing of terraces was calculated using Ramser and Morgan method. The results obtained were combined with the results from the USLE model. Hydraulic methods have shown greater spacing for the Mielnica catchment (loess soils) compared to the Ner basin (clay loam). For the USLE model, the larger spacing was calculated for the Ner basin. From the practical application to the acceptance of land user will be the maximum distance calculated by different methods. The highest terrace spacing values were obtained using the Morgan method for the Mielnica catchment, for the Ner catchment model USLE.
\end{abstract}

Key words: soil erosion, terraces, spacing, USLE model, probability

\section{INTRODUCTION}

Conservation-effective measures, which brought about the desired reduction in erosion and sedimentation, enhanced soil resilience and resorted eroded/degraded soils, include no-till (NT) farming, CRP, cover cropping, strip cropping, vegetation barriers, elimination of summer fallow, and the installation of conservation devices such as terraces, waterways, diversion ditches, gabions, and drop structures (Gassel 1982, Wawer et al. 2013). The conservation of water (increasing infiltration, decreasing runoff, reducing evaporation and increasing soil water storage) and that of soil go hand-in-hand; therefore, practices which conserve water also conserve soil (Arnaez et al. 2015). Numerous publications in countries such as Spain (Douglas et al. 1994, Gallart et al. 1994, Cerdà 1998), Italy (Mauro 2011, Tarolli et al. 2014), Germany (Lóczy 1998), Mexico (Mountjoy and Gliessman 1988), Nepal (Gardner and Gerrard 2003), and China (Quine et al. 1999, Cao et al. 2013, Yi et al. 2017), as well as numerous conferences, confirm the significance of both the threat posed by the erosion process, as well as the methods of protection against this phenomenon (Arnaez et al. 2015). Terracing is one 
possible way to stop or reduce the degrading effect of soil erosion. It is one of the oldest means of saving soil and water (Dorren and Rey 1998, Patro et al. 2008, Schönbrodt-Stit et al. 2013). Moreover, it is the most widely used soil conservation practice throughout the world (Hanway and Laflen 1974, Mountjoy and Gliessman 1988, Sutikto and Chikamori 1993, Franti et al. 1998, Ruecker et al. 1998, Quine et al. 1999, Kasai et al. 2001, Yi et al. 2017). Nowadays, terracing is still, in many cases, promoted as being the best management practice for effective soil and water conservation (Ramos and Porta 1997, Wheaton and Monke 2001, Hussain et al. 2016). Terraces are one of the tools for directing the circulation of water in a catchment, facilitating the change of surface runoff into baseflow runoff or facilitating the retention of water in reservoirs. In this way, the concept of slowing water circulation, contributing to minimizing the so-called fast means of water runoff from a geomorphological hill environment, or closing this cycle within an area of a river water catchment was realized (Baryła and Pierzgalski 2001). In Poland, ridge terraces on agricultural soils are basically not applied. One of the reasons behind such a state of things may be the lack of theoretical and practical bases for designing them. Including ridge terraces in the arsenal of tools used for the protection of arable land against erosion is intentional, considering that in the climatic conditions of our country, in periods of snowmelts and heavy summer rainfalls, arable lands, as a result of inadequate coverage with vegetation, are especially at risk of the water erosion of soil. By limiting water runoff from agricultural fields or forest areas, ridge ter- races could significantly influence how water resources are shaped. The problem subjected to analysis in this work was calculating the spacing of terraces for various rainfall probabilities under conditions of loess and clay soils. The calculations were carried out on the basis of own research results. It was assumed that the popularity and application of ridge terraces in Poland, as one of the technical means of protecting arable lands from erosion, is possible and justified. This has been demonstrated by their practical application in many countries, where such terraces have been used to as tools for preventing erosion.

\section{MATERIAL AND METHODS}

The studies were carried out in the area of two catchments: the Ner river and the Mielnica waterflow in Lower Silesia Province (Polish województwo dolnośląskie). Detailed soil and meteorological studies were carried out in Puczniew (Ner catchment) and in Boleścin (Mielnica catchment).

The Mielnica catchment is located in the region of Trzebnica Hills (Polish Wzgórza Trzebnickie) (Lower Silesia Province). The climate of Trzebnica Hills as a mesoregion of the Trzebnica Embankment (Polish Wał Trzebnicki), according to Romer, is considered as the climate of the basin and mountain plain regions (quoted from Bac et al. 1993). The annual rain totals range from, on average from 650 to $800 \mathrm{~mm}$, while the average number of rainy days (with rainfalls exceeding $0.1 \mathrm{~mm}$ ) ranges from 140 to 160 . In the period between April and November, there are an average of 
3.52 days with rainfalls of over $20 \mathrm{~mm}$. Thunderstorms occur on average during a period of 20.1 days (Żmuda 2006). The geological makeup of Trzebnica Hills is dominated by tertiary and quaternary soil deposits. Surface deposits are mainly quaternary sediments, such as: loesses, glacial clays and glaciofluvial deposits. Studies carried out by Żmuda (1998) in the Mielnica catchment showed the dominant soil type to be loesses (Table 1). This area, in terms of altitude, ranges between the values of 169.38 and $246.10 \mathrm{~m}$ above sea level. The average slope of the catchment is $2.9 \%$, whereas the average gradient of slope is $7-8 \%$.

The climate of the Ner catchment is characteristic of the Land of Great Valleys (Polish Kraina Wielkich Dolin), included in areas of a temperate climate with transitional features between a continental (dry, with a high amplitude of yearly temperatures) climate of Eastern Europe and an oceanic (humid, with a lower amplitude of temperatures) climate of Western Europe, with the influence of the continental climate being quite pronounced (Romer 1949). The annual total of rainfalls falls within 600 $\mathrm{mm}$. The majority of rainfalls are noted in July, while in winter, these amount to approximately $100 \mathrm{~mm}$. Arable lands of the Ner catchment are located on quaternary deposits, created as a result of a glacier, mainly from boulder-clays of ground moraine of ancient glaciations, and sands of glacial aggradations on boulder clay. The land is slightly undulating, with considerable slopes to the north and south and a slight slope to the north-west. The altitude of the land is approximately $143-153 \mathrm{~m}$ above sea level (Wanke 1977). The agricultural land of Puczniew can be representative of a large share of arable lands in Poland, i.e. clay soils, and thus soils characterized by poor permeability.

Rainfall data from the period of 1971-2002 of the Puczniew meteorological station, made available by IMGW in Warsaw, as well as rainfall data from 1976-2005 from the meteorological station in Boleścin of the Wroclaw University of Environmental and Life Sciences (Institute of Environmental Protection and Development). Maximum values for each year were selected from daily rainfall totals. The Kołomogorov-Smirnov test was carried out in a further analysis in order to assess whether a given feature follows a normal distribution pattern. The spacing of terraces was determined according to Ramser's (after Ostromęcki 1947) and Morgan's formulas for the given probabilities of maximum daily rainfalls of 1,20 and $50 \%$. The obtained results were then compared to NRCS guidelines (2011).

TABLE 1. Granulometric content of soil samples of surface layers of soil $(0-25 \mathrm{~cm})$ of the Mielnica river (Boleścin) and Ner river (Puchniew) catchments

\begin{tabular}{|c|c|c|c|c|c|c|c|}
\hline \multirow[b]{2}{*}{ Catchment } & \multicolumn{6}{|c|}{ Content of fractions (\%) } & \multirow{2}{*}{$\begin{array}{c}\text { Soil } \\
\text { texture }\end{array}$} \\
\hline & $1-0.1 \mathrm{~mm}$ & $\begin{array}{c}0.1- \\
-0.05 \mathrm{~mm}\end{array}$ & $\begin{array}{c}0.05- \\
-0.02 \mathrm{~mm}\end{array}$ & $\begin{array}{c}0.02- \\
-0.006 \mathrm{~mm}\end{array}$ & $\begin{array}{c}0.006- \\
-0.002 \mathrm{~mm}\end{array}$ & $<0.002 \mathrm{~mm}$ & \\
\hline Mielnica & 7.0 & 9.1 & 46.3 & 20.5 & 8.6 & 8.5 & loesses \\
\hline Ner & 62 & 8 & 6 & 6 & 6 & 12 & clays \\
\hline
\end{tabular}


Using Ramser's method (after Ostromęcki 1947), the capacity of the reservoir collecting water above the embankment is determined. The capacity of the reservoir depends on the height of the embankment and the slope of the land above the place where it is located. In the case of identical embankment height - the lower the slope of the hillside, the higher the capacity. The spacing of ridge terraces $(L)$ is calculated according to the formula:

$$
L=\frac{h}{2 \sigma R}\left(\frac{d}{2}+\frac{h}{S}\right)
$$

where:

$L$ - horizontal terrace spacing;

$h$ - height of embankment [m];

$\sigma$ - runoff coefficient (-);

$R$ - rainfall (m);

$d$ - width of foot of the ridge (m);

$S$-slope of terrain (-).

According to the intention of Morgan's formula (1986), being the result of transforming Manning's hydraulic formula to determine the amount of water running off in the form of surface runoff, the distribution of ridge terraces is calculated as follows:

$$
L=\frac{v^{5 / 2} n^{3 / 2}}{(R-i) \sin ^{3 / 4} \theta \cos \theta}
$$

where:

$v$ - the acceptable speed of runoff water $\left(\mathrm{m} \cdot \mathrm{s}^{-1}\right)$;

$n$ - coefficient dependent on the roughness of the surface $\left(\mathrm{m}^{-1 / 3} \cdot \mathrm{s}^{-1}\right)$;

$R$ - rainfall $\left(\mathrm{mm} \cdot \mathrm{h}^{-1}\right)$

$i$ - infiltration $\left(\mathrm{mm} \cdot \mathrm{h}^{-1}\right)$;

$\theta$ - inclination angle of slope $\left(^{\circ}\right)$.

The calculations for the above-mentioned objects were carried out assuming the following dimensions of terraces: height of embankment $(h)-0.3 \mathrm{~m}$, width of embankment $(d)-3$ m (Fig. 1). Moreover, the following assumptions were made: the runoff coefficient using Ramser's method for loamy-sandy soil and impermeable subsoil as equal to 0.70 for a slope of up to $5 \%$, and 0.75 for a slope of over $5 \%$ under conditions present in Puczniew, and for loess soil - equal to 0.50 for a slope of up to $5 \%$ and 0.55 for a slope of over $5 \%$ under conditions of the Mielnica watercourse catchment.

Applying Morgan's formula (1986) calls for carrying out an evaluation of the values of features constituting the bases for the calculation. The following assumptions were made for the conditions of the catchment in Puczniew: acceptable speed of water flowing down the surface of land $-0.75 \mathrm{~m} \cdot \mathrm{s}^{-1}$. For conditions present in Boleścin in the area of

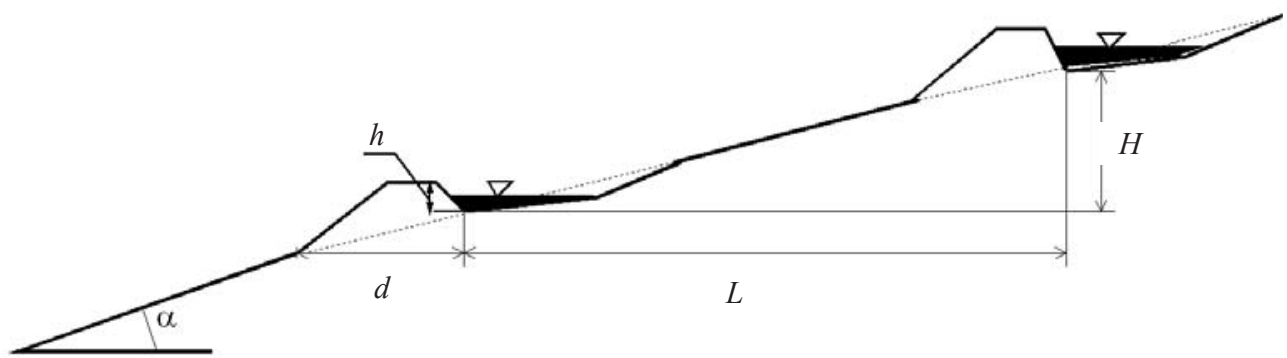

FIGURE 1. Diagram of ridge terrace: $H$ - vertical spacing - height of terrace $(\mathrm{m}), L$ - horizontal spacing (m), $d$ - width of embankment (m), $h$ - height of embankment (m), $a$-inclination angle of slope $\left(^{\circ}\right)$ 
Trzebnica Hills, the following were accepted: speed of water flowing down the surface of the land $-1.0 \mathrm{~m} \cdot \mathrm{s}^{-1}$, roughness coefficient accepted as 0.01 (soils without covering). Soil permeability were determined by filtration coefficient. The size of this parameter was determined by laboratory analysis of soil samples in de Wita equipments (Stapel 1982). The filtration coefficient for the Mielnica catchment was $11.63 \mathrm{~mm} \cdot \mathrm{h}^{-1}$, for Ner catchment $6.25 \mathrm{~mm} \cdot \mathrm{h}^{-1}$. Spacing calculation Ramser's and Morgan's formula was carried out for various probabilities $(1,50,90 \%)$ of rainfalls occurring in both catchments.

The spacing of terraces can be calculated using models, but a large amount of data needs to be verified. An alternative may be the USLE equation (Wischmeier and Smith 1978). The slope length used when checking soil loss for a proposed terrace spacing is the distance from the terrace ridge to the next lower terrace channel measured along the natural flow direction (NRCS 2010).

In the past few decades, the USLE was applied in many regions of the world where an estimation of its factors became available (Hussein et al. 2016). On gently sloping land, anticipated runoff and the economical terrace cross section size may determine spacing rather than soil loss tolerance between terraces (ASAE 1989). The USLE is:

$$
A=R K L S C P
$$

where:

$A$ - mean annual (seasonal) soil loss $\left(\mathrm{t} \cdot \mathrm{ha}^{-1} \cdot \mathrm{year}^{-1}\right)$;

$R$ - rainfall-runoff erosivity factor $\left(\mathrm{MJ} \cdot \mathrm{ha}^{-1} \cdot \mathrm{mm} \cdot \mathrm{h}^{-1}\right)$;

$K$ - soil erodibility factor $\left(\mathrm{t} \cdot \mathrm{h}^{-1} \cdot \mathrm{MJ}^{-1}\right.$. $\cdot \mathrm{mm}^{-1}$ );
L - length of slope factor (-);

$S$ - steepness of slope factor (-);

$C$ - cover-management factor (-);

$P$ - supporting practice factor (-).

The horizontal terrace spacing $-\lambda$ (horizontal projection of the slope length parallel to the soil surface) is calculated from:

$$
L=A / R K S C P=(\lambda / 22.1)^{m}
$$

where:

$\lambda$ - horizontal terrace spacing $(\mathrm{m})$;

$m$-slope length exponent (Stone and Hilborn 2000): $m=0,2$, if $s \leq 1.0 \%$; $m=0.3$, if $1.0<s<3.0 \%$; $m=0.4$, if $3.0 \leq s<5.0 \% ; m=0.5$, if $s \geq 5.0 \%$.

In the USLE equation $R$ was used for Wroclaw calculated by Licznar and Rojek (2002) and $R$ for Puczniew calculated by Baryła (2012). Parameter $K$ was determined using nomogram [FAO 1996b]. By converting to SI units, the value obtained was multiplied by $K_{S I}=$ $=0.1317 K_{U S}$. The plant cover ratio was $C=1$ (Koreleski 1992, Molnar and Julien 1998), parameter $P$ was used for terracing $P=0.3$. Parameter $S$ is calculated according to the equations proposed by Wischmeier and Smith (1978).

In many countries, empirical equations based on the formula $L=\left(x_{S}+y\right)$ $\left(100 \cdot \mathrm{s}^{-1}\right)$ are used (SCS, NRCS 1982). Determining the spacing of terraces according to ASAE (1989), it was assumed that $x$-variable dependant on the geographical zone equal to 0.12 and 0.24 and $y$ (variable dependant on the susceptibility of soil to erosion) equal to 0.3 and $1.2, s$ - decrease in \%. In calculations it was adopted for Mielnica catchment area $x=0.12, y=0.3$, for Ner catchment $x=$ $=0.20, y=1.0$. 


\section{RESULTS AND DISCUSSION}

The basic parameters of the normal distribution as well as the results of the Kolgomorov-Smirnov test for the analyzed set of maximum daily rainfall totals have been compiled in Table 2 .

TABLE 2. Describing parameters analyzed populations and values of the Kolgomorov-Smirnov test

\begin{tabular}{|l|c|c|c|c|}
\hline Parameter & $\begin{array}{c}\text { Mean } \\
(\mathrm{mm})\end{array}$ & $\begin{array}{c}\text { SD } \\
(\mathrm{mm})\end{array}$ & $\lambda_{k s}$ & $\lambda_{k s \alpha}$ \\
\hline$P_{\max }$ Puczniew & 36.90 & 13.77 & 1.04 & 1.354 \\
\hline$P_{\max }$ Mielnica & 40.70 & 12.15 & 0.53 & 1.354 \\
\hline
\end{tabular}

The empirical value of the test $\left(\lambda_{k s}\right)$ was lower than the critical value $\left(\lambda_{k s \alpha}\right)$, and thus, there is no basis to reject the hypothesis regarding the empirical aconsistency of the distribution function with the class of normal distribution functions (Fig. 2).

The spacing of terraces calculated according to Ramser's formula (Fig. 3) showed great differences in their dimensioning. For a rainfall of $1 \%$ under conditions of the Mielnica Catchment in Trzebnica Hills for a slope of 5\% was $33 \mathrm{~m}$, whereas for the Ner river catchment - the spacing was $17 \mathrm{~m}$. The occurrence of such a difference in the values of calculated spacing is connected mainly with the input parameters assumed in Ramser's formula. The calculated values spacing of the terraces by the Morgan's method (Fig. 4) for the probability of 1\% for a slope of 5\% in the Mielnica catchment was $33 \mathrm{~m}$, in the Ner catchment was $23 \mathrm{~m}$. For the Mielnica catchment area, for the probability of $1 \%$, the calculated spacing for a slopes 5 and $10 \%$ Morgan's and Ramser's method was the same $(33$ and $20 \mathrm{~m})$. In the Ner catchment however, the spacing calculated with the Ramser's and Mogan's models for the probability of $1 \%$ was different.

The results of calculating the spacing of terraces for the greatest rainfall event
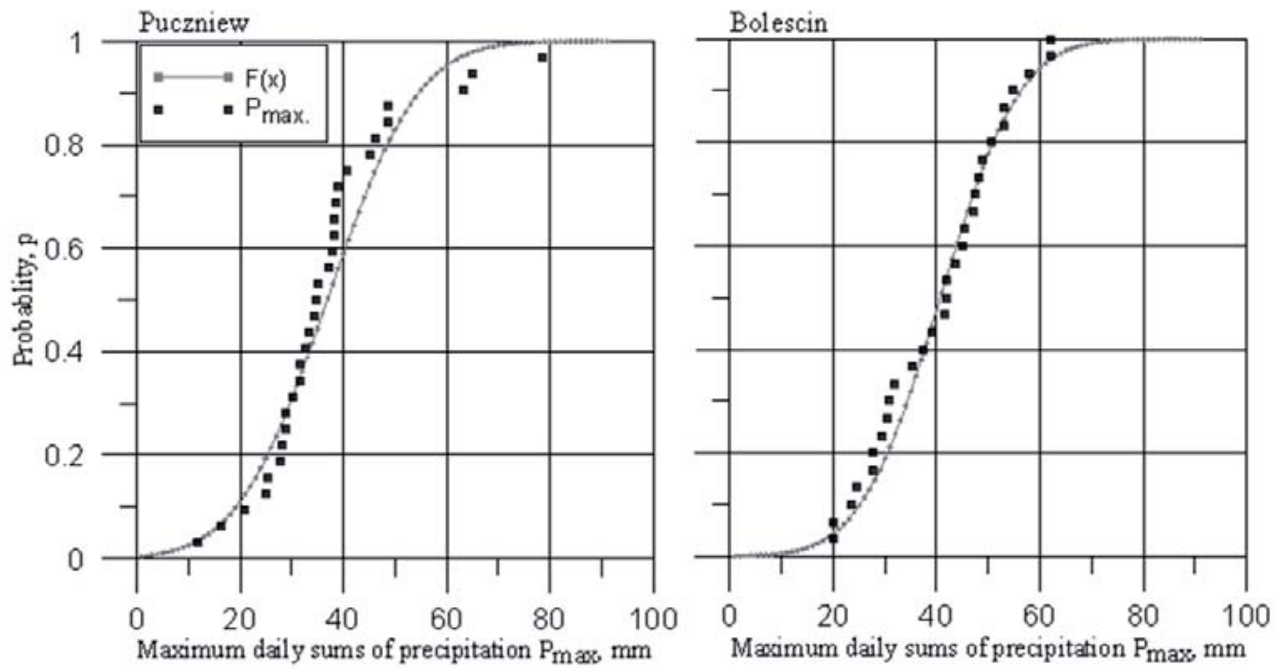

FIGURE 2. Graph of the distribution function for maximum daily sums of precipitation for Puczniew (Baryła 2012) and Boleścin 

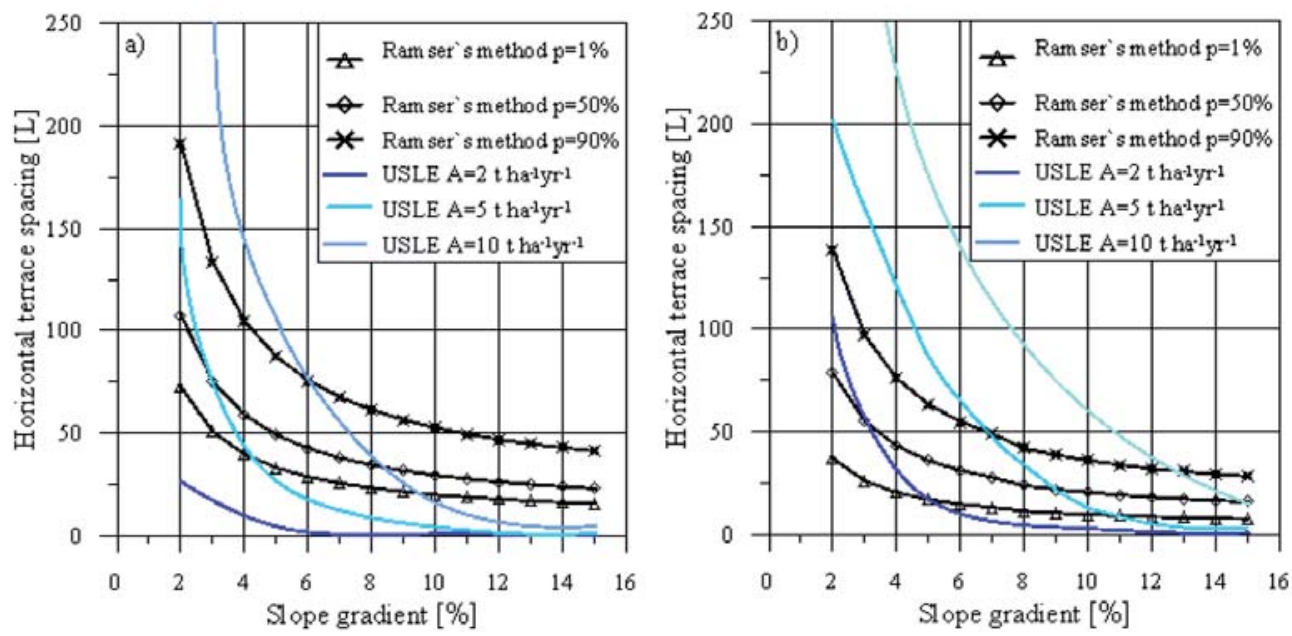

FIGURE 3. Terrace spacing calculated using Ramser's formula for conditions of the Mielnica (a) and Ner (b) river catchments

observed in Puczniew, determined using Morgan's and Ramser's methods, were compared with the spacing determined using the USLE method. In this method, the indicator of the erosiveness of the rainfall and surface runoff $(R)$ is used to determine the dimensions of terraces. For the catchment in Puczniew, its average value was 48.3 Je (Baryła 2012), whereas for the one in Boleścin, the value of $63.7 \mathrm{Je}$ calculated by Licznara and Rojka (2002) for Wroclaw was assumed.

The spacings calculated for the USLE method of loss $5 \mathrm{t} \cdot \mathrm{ha}^{-1} \cdot \mathrm{year}^{-1}$ shows
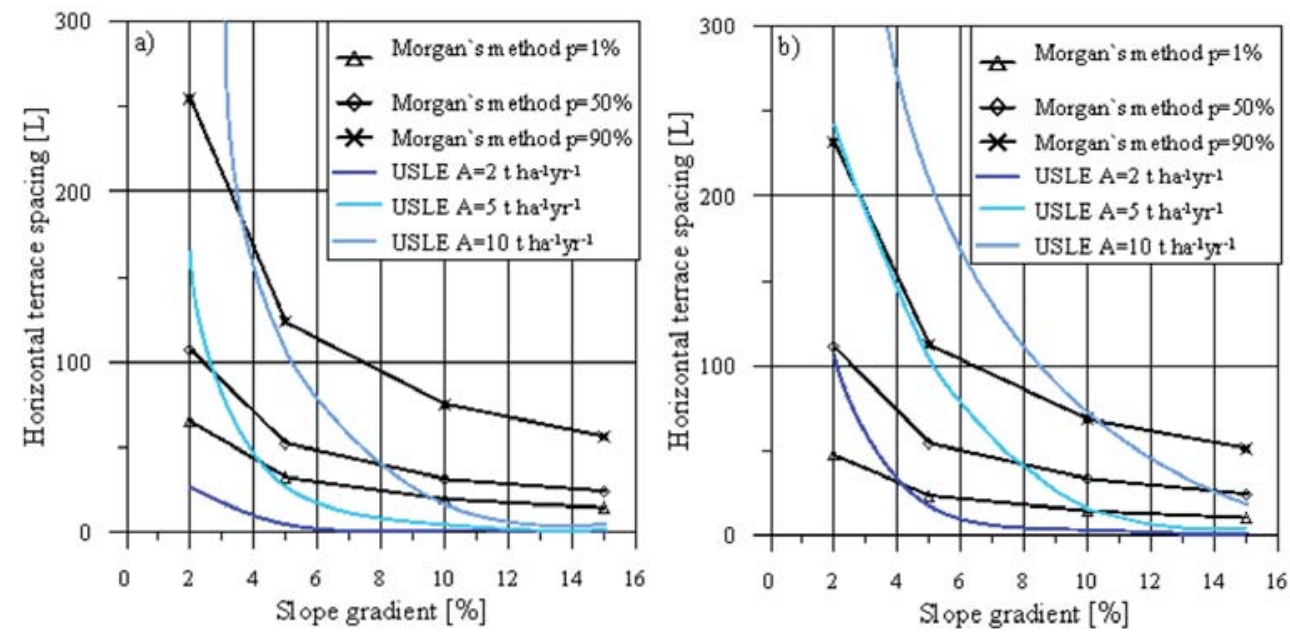

FIGURE 4. Terrace spacing calculated using Morgan's formula for conditions of the Mielnica (a) and Ner (b) river catchments 
significant differences in spacing between the two catchments. For a 5\% slope gradient in the Mielnica catchment the spacing was $26 \mathrm{~m}$, for the Ner catchment $75 \mathrm{~m}$. The Ner catchment area is nearly double that of the hydraulic model (Ramser's and Morgan's).

A specific type of indicator for introducing ridge terraces to eroded areas are the recommendations of Prochal (1984). On the basis of research carried out in the USA, he recommends the follow-

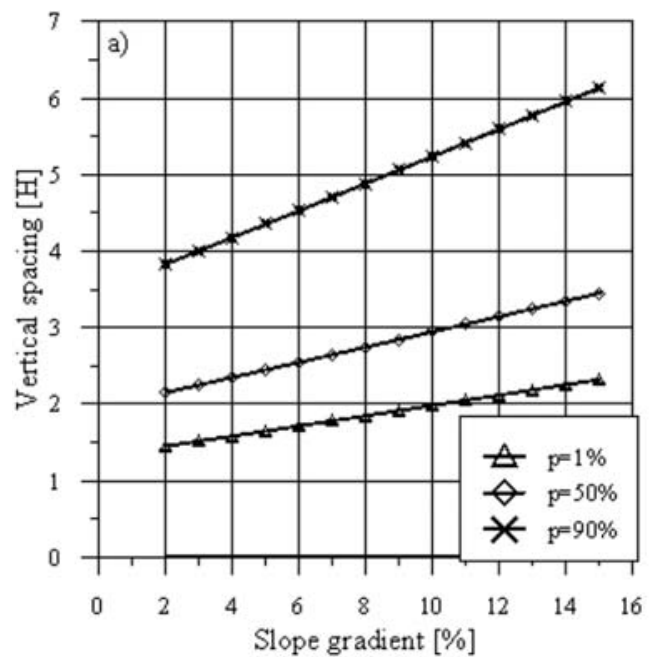

ing spacing for small slopes: $38 \mathrm{~m}$ - for a slope of $2 \%, 22 \mathrm{~m}$ - for $5 \%, 20 \mathrm{~m}$ for $6 \%$, and $16 \mathrm{~m}$ for $10 \%$. These are values similar to the values obtained by the Morgan's method for the probability of a $1 \%$. The length of the constructed terraces should not exceed $300 \mathrm{~m}$ [Hudson 1995].

Table 3 shows the horizontal and vertical interval distances between terraces for several design criteria for 5 and $10 \%$ slope gradient, probability $50 \%$. Calculated spacing values were differnt

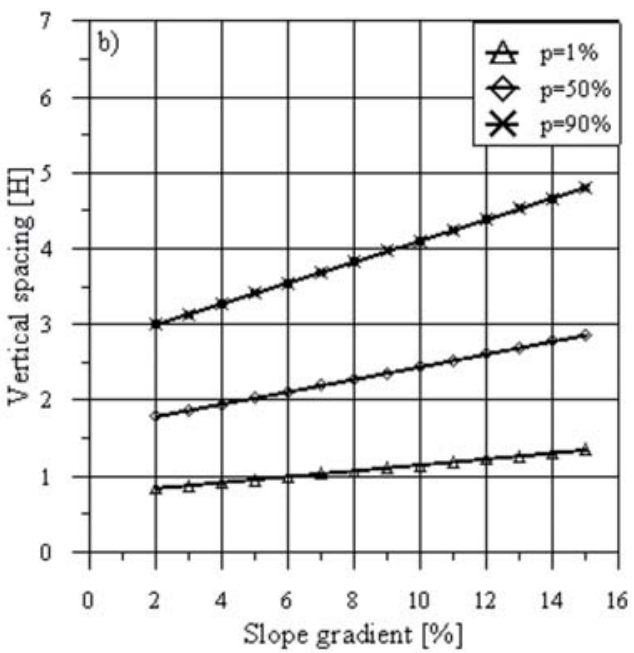

FIGURE. 5 Vertical spacing $(H)$ calculated using Ramser's formula for Mielnica (a) and Ner (b) catchments

TABLE 3. Horizontal and vertical interval distances between terraces following several design criteria

\begin{tabular}{|l|c|c|c|c|c|}
\hline \multirow{2}{*}{ Method } & \multirow{2}{*}{ Slope $(\%)$} & \multicolumn{2}{|c|}{ Horizontal distance $(\mathrm{m})$} & \multicolumn{2}{c|}{ Vertical interval $(\mathrm{m})$} \\
\cline { 2 - 6 } & & Mielnica & Ner & Mielnica & Ner \\
\hline \multirow{2}{*}{$\begin{array}{l}\text { SCS-USDA } \\
L=(x s+y)\left(100 \cdot \mathrm{s}^{-1}\right)\end{array}$} & 5 & 18 & 40 & 0.9 & 2.0 \\
\cline { 2 - 6 } & 10 & 15 & 30 & 1.5 & 3.0 \\
\hline \multirow{2}{*}{ Ramser's $p=50 \%$} & 5 & 49 & 34 & 2.5 & 2.0 \\
\cline { 2 - 6 } & 10 & 30 & 20 & 3.0 & 2.4 \\
\hline \multirow{2}{*}{ Morgan's $p=50 \%$} & 5 & 55 & 54 & 2.8 & 2.7 \\
\cline { 2 - 6 } & 10 & 33 & 32 & 3.3 & 3.2 \\
\hline \multirow{2}{*}{$\begin{array}{l}\text { USLE from } L \text {-factor } \\
\text { A } 5 \text { tha }\end{array}$} & 5 & 26 & 75 & 1.3 & 3.8 \\
\hline \multirow{2}{*}{ Prochal $(1984)$} & 10 & 4 & 17 & 0.4 & 1.7 \\
\cline { 2 - 6 } & 5 & 22 & 22 & 1.1 & 1.1 \\
\cline { 2 - 6 } & 10 & 16 & 16 & 1.6 & 1.6 \\
\hline
\end{tabular}


for different patterns for the two catchments. In literature many authors show problem in which equation should be used to calculate tarraces at a distance (Ramos and Porta 1997). Standard design criteria commonly used in several geographic areas lead to very diverse results as shown in this article. In practical use for acceptable land use will be the maximum distances of the terraces. The calculated horizontal distance of the terraces by the Morgan's method (based on hydraulic calculations) showed the highest values, for a $5 \%$ slope gradient in the Mielnica catchment $(55 \mathrm{~m})$. For the Ner catchment the highest spacing was for the USLE's method (75 m).

\section{CONCLUSIONS}

Practical application in many countries showed that terraces can significantly prevent processes leading to the degradation of land, such as the excessive erosion of soils and landslides. The requirement for this is well-planned, adequate construction, and later - proper conservation. There are many types of terraces, and it cannot be unanimously determined whether this type of terrace is the best, since the type as well as amount of terrace spacing depends on local, climatic, and soil conditions in the given area (as demonstrated in the present article). The terrace spacing calculated in this article for two catchments revealed different values. The region of the Mielnica catchment was dominated by loess soils, whereas the Ner catchment - clay soils. The meteorological conditions of the two catchments were also dissimilar. An important aspect of constructing terraces is the fact that they must be connected with additional soil protection practices, the easiest of which is maintaining plant cover year-round. Attention should be drawn to the fact that, in regards to terraces or any form of soil protection, most farmers, in practice, focus mainly on production rather than protection. Ideal solutions would be to combine these two aspects; however, terraces do not increase crop yield, though an important aspect is the efficiency they exhibit when it comes to protecting soil against erosion and increasing soil retention, by which they decelerate the water cycle in the river catchment.

\section{REFERENCES}

ARNAEZ J., LANA-RENAULT N., LASAMTA T., RUIZ-FLANO P., CASTROVIEJO J. 2015: Effects of farming terraces on hydrological and geomorphological processes. Catena 128, 122-134. ASAE Standard 1989.

BAC S., KOŹMIŃSKI C., ROJEK M. 1993: Agrometeorologia [Agrometeorology]. PWN, Warszawa.

BARYŁA A. 2012: Określenie strat gleby przy różnych prawdopodobieństwach występowania deszczów erozyjnych dla stacji meteorologicznej Puczniew [Estimating the loss of soil at different probabilities of erosive rainfalls - A case study of experimental farm in Puczniew]. Woda - Środowisko - Obszary Wiejskie [Water - Environment - Rural Areas] (X-XII), 12, 4 (40) [in Polish].

BARYŁAA., PIERZGALSKI E. 2001: Tarasy grzbietowe a kształtowanie zasobów wodnych [Terraces and water resources management]. PN IKS 22, 443-450. [in Polish].

CAO Y., WU Y., ZHANG Y., TIAN J. 2013: Landscape pattern and sustainability of a 1300-year-old agricultural landscape in subtropical mountain areas, Southwest- 
ern China. Int. J. Sustain. Dev. World Ecol. 20 (4), 349-357.

CERDÀ A. 1998: The influence of aspect and vegetation on seasonal changes in erosion under rainfall simulation on a clay soil in Spain. Can. J. Soil Sci. 78, 321-330.

DORREN L., REY F. [1998]: A review of the effect of terracing on erosion. Retrieved from http://eusoils.jrc.ec.europa.eu/projects/scape/uploads/103/Dorren_Rey.pdf.

DOUGLAS T.D., KIRKBY S.J., CRITCHLEY R.W., PARK G.J. 1994: Agricultural terrace abandon-ment in the Alpujarra, Andalucía, Spain. Land Degrad. Dev. 5, 281-291.

FAO 1996: K-factor determination. Retrieved from http://www.fao.org/docrep/ t1765e/t1765e0f.htm\#soil\%20erodibility [accessed 20.05.2010].

FRANTI T G., PETER C.J., TIERNEY D.P., FAWCETT R.S., MYERS S.A. 1998: Reducing herbicide losses from tile-outlet terraces. J. Soil Water Conserv. 53 (1), 25-31.

GALLART F., LLORENS P., LATRON J., 1994: Studying the role of old agricultural terraces on run-off generation in a small Mediterranean mountainous basin. J. Hydrol. 159, 291-303.

GARDNER R., GERRARD J. 2003: Runoff and soil erosion on cultivated rainfed terraces in the Middle Hills of Nepal. Appl. Geogr. 23, 23-45.

GASSEL D.K. 1982: Tillage effects on soil bulk density and mechanical impedance In: P.W. Unger, D.M. Van Doren Jr (Eds), Predicting tillage effects on soil physical properties and processes (pp. 45-67). Am. Soc. Agron. Sp Publication 44, Madison, WI, USA, 44, 45-67.

HANWAY J., LAFLEN J.M. 1974: Plant nutrient losses from tile outlet terraces. J. Environ. Qual. 3 (4), 351-356.

HUDSON N. 1995: Soil conservation (3rd edn.). Iowa State University Press, Ames, Iowa, USA.

HUSSEIN M., AMIEN I. KARIEM T. 2016: Designing terraces for the rainfed farming region in Iraq using the RUSLE and hydraulic principles. Int. Soil Water Conserv. Res. 4, 1, 39-44.

KASAI M., MARUTANI T., REID L.M., TRUSTRUM N.A. 2001: Estimation of temporally averaged sediment delivery ratio using aggadational terraces in headwater catchments of the Waipaoa river, North Island, New Zealand. Earth Surface Proc. Landforms 26, 1-16.

KORELESKI K. 1992: Próby oceny natężenia erozji wodnej [Attempts to assess the intensity of water erosion]. Zesz. Nauk. AR Krak., Ses. Nauk. 35, 91-100.

LICZNAR P., ROJEK M. 2002: Erozyjność deszczy południowo-zachodniej Polski na przykładzie stacji Wrocław-Swojec. [Rainfall erosivity of South-Western Poland on the base of Wroclaw Swojec gauging station example]. PN IKS 11, 2 (25), 5-14.

LÓCZY D. 1998: Man-made terraces in a German agricultural landscape. Geogr. Fis. Dinamica Quaternaria 21 (1), 55-59.

MAURO G. 2011: Agricultural terraced landscapes in the province of Trieste (Northeastern Italy). In: B. Murgante et al. (Eds). Geocomputation. Sustainability \& Environment Planning B. SCI 348, 91-109.

MORGAN R.P.C. 1986: Soil erosion and conservation. Longman Scientific \& Technical, Essex, UK.

MOLNAR D.K., JULIEN P.Y. 1998: Estimation of Upland Erosion Using GIS. Comp. Geosci. 24, 2, 183-192.

MOUNTJOY D.C., GLIESSMAN S.R. 1988: Traditional management of a hillside agroecosystem in Tlaxcala, Mexico: an ecologically based maintenance system. Am. J. Altern. Agric. 3, 1-10.

Natural resources conservation service (NRCS) 2011. Conservation Practice Standard 2011. Terrace code 600.

OSTROMECCKI J. 1947: Erozja gleb jako zagadnienie melioracyjne [Erosion of soil as drainage question]. Gospodarka Wodna 4-5, 1-2 [in Polish].

PATRO M., WEGOREK T., ZBALA T. 2008: Ploughed-on terraces in loess landscape 
of strongly developed high plains. Ann. Warsaw Univ. Life Sci. - SGGW Land Reclam. 39, 95-101.

PROCHAL P. 1984: Melioracje przeciwerozyjne [Drainage]. Wydawnictwo AR, Kraków [in Polish].

QUINE T.A., WALLING D.E., ZHANG X. 1999: Tillage erosion, water erosion and soil quality on cultivated terraces near Xifeng in the Loess Plateau, China. Land Degrad. Dev. 10, 251-274.

RAMOS M.C., PORTA J. 1997: Analysis of design criteria for vineyard terraces in the Mediterranean area of North East Spain. Soil Technol. 10, 155-166.

ROMER E. 1949: Regiony klimatyczne Polski [Climatic regions of Poland]. Wrocławskie Towarzystwo Naukowe, Wrocław.

RUECKER G., SCHAD P., ALCUBILLA M.M., FERRER C. 1998: Natural regeneration of degraded soils and site changes on abandoned agricultural terraces in Mediterranean Spain. Land Degrad. Dev. 9, 179-188.

SCHÖNBRODT-STITT S., BEHRENS T., SCHMIDT K., SHI X., SCHOLTEN T. 2013: Degradation of cultivated bench terraces in the Three Gorges Area: Field mapping and data mining. Ecol. Indicators 34, 478-493.

STĄPEL Z. 1982: Metodyka oznaczania współczynnika filtracji gleb mineralnych do określenia rozstawy drenów [Methodology for determination of mineral soil filtration coefficient for determining drainage spacing]. Instytut Melioracji i Użytków Zielonych, Warszawa.

STONE R.P., HILBORN D. 2000: Universal soil loss equation (USLE). Ontario. Min. Agricult. Food Rural Affairs. Retrieved from http://www.omafra.gov.ca/english/ engineer/facts/00-01.htm. Factsheet. Order. 1.

SUTIKTO T., CHIKAMORI K. 1993: Evaluation of Philip's infiltration equation for cultivated upland terraces in Indonesia. J. Hydrol. 143 (3-4): 279-295.
TAROLLI P., PRETI F., ROMANO N. 2014: Terraced landscape: from an old best practice to apotential hazard for soil degradation due to land abandonment. Anthropocene 6, 10-25.

WANKE A. 1977: Działanie drenowania i poprawa jego skuteczności w glebach słabo przepuszczalnych [Effect of drainage and improvement of its effectiveness in poorly permeable soils]. $\mathrm{PhD}$ thesis, Warszawa [manuscript] [in Polish].

WAWER R., NOWOCIEN E., PODOLSKI B., PUDEŁKO R., 2013: Protective role of grassland against soil water erosion caused by extreme rainfall events as compared to black fallow. J. Food Agri. Environ. 11 (1), 1069-1071.

WISCHMEIER W.H., SMITH D.D. 1978: Predicting rainfall erosion losses. USDA Agric. Handb. 537. U.S. Gov. Print. Office, Washington D.C.

WHEATON R.Z. MONKE E.J. 2001: Terracing as a 'Best Management Practice' for controlling erosion and protecting water quality. Agricult. Eng. 114. Retrieved from http://www.agcom.purdue. edu/AgCom/Pubs/AE/AE-114.html

YI Z., MINGCHANG S., XIN Z., XIAOJING W., ZHIDONG L., YUAN Z. 2017: Methods for automatic identification and extraction of terraces from high spatial resolution satellite data (China-GF-1). Int. Soil Water Conserv. Res. 5 (1), 17-25.

ŻMUDA R. 1998: Natężenie erozji wodnej w małej zlewni rolniczej Wzgórz Trzebnickich na tle wybranych elementów hydrometeorologicznych [Water erosion intensity in small agricultural catchment in Trzebnica Hills on the background of selected hydrometeorological elements]. Zesz. Nauk. AR Wroc. 349, Inż. Środ. 10, 233-259 [in Polish].

ŻMUDA R. 2006: Funkcjonowanie systemu transportu fluwialnego $\mathrm{W}$ małej zlewni zagrożonej erozją wodną gleb [Fluvial transport system functioning in small catchment threatened by soil water erosion]. Uniwersytet Przyrodniczy, Wrocław [in Polish]. 
Streszczenie: Dobór rozstawy tarasów grzbietowych na gruntach ornych $w$ środkowej i potudniowo-zachodniej części Polski. Praktyka wielu krajów wykazała, że tarasy mogą znacznie zapobiegać procesom prowadzącym do degradacji gruntów, takich jak nadmierna erozja gleb, osuwiska. Warunkiem jest dobre rozplanowanie, właściwa konstrukcja, a potem prawidłowa konserwacja. W Polsce jest to metoda mało popularna. W artykule wyliczono rozstawę tarasów grzbietowych dla dwóch zlewni - w środkowej i południowo-zachodniej części Polski. Wykorzystano dane meteorologiczne i glebowe dla stacji Puczniew (zlewnia Ner) i stacji Boleścin (zlewnia Mielnica). Wykonano test Kołmogorowa-Smirnowa, aby ocenić zgodność danej cechy $\mathrm{z}$ rozkładem normalnym, następnie opracowano dystrybuantę rozkładu prawdopodobieństwa. Dla prawdopodobieństwa 1, 50 i 90\% wyliczono rozstawę tarasów za pomocą wzorów Ramsera i Morgana. Uzyskane wyniki zestawiono z wynikami z modelu USLE. Hydrauliczne metody wykazały większe rozstawy dla zlewni Mielnicy (gleby lessowe) w porównaniu ze zlewnią Ner (gleby gliniaste). W przypadku modelu USLE większe rozstawy wyliczono dla zlewni Ner. Z punktu widzenia praktycznego zastosowania do zaakceptowania przez użytkownika gruntów będą odległości maksymalne, jakie wyliczono różnymi metodami. Największe wartości rozstawy tarasów otrzymano, wykorzystując metodę Morgana dla zlewni Mielnica, a dla zlewni Ner stosując model USLE.

\section{MS received June 2017}

\section{Authors' address:}

Anna Baryła

Katedra Kształtowania Środowiska

Wydział Budownictwa i Inżynierii Środowiska SGGW

Nowoursynowska 166, 02-787 Warszawa

Poland

e-mail: anna_baryla@sggw.pl 